\title{
Vitamin D status in children and adults in Sweden: dietary intake and 25-hydroxyvitamin D concentrations in children aged 10-12 years and adults aged $18-80$ years
}

\author{
Cecilia Nälsén ${ }^{1 *}$, Wulf Becker ${ }^{1,2}$, Monika Pearson ${ }^{1}$, Peter Ridefelt ${ }^{3}$, Anna Karin Lindroos ${ }^{1,4}$ (D), \\ Natalia Kotova ${ }^{1}$ and Irene Mattisson ${ }^{1}$ \\ ${ }^{1}$ Department of Risk Benefit Assessment, Division of Science, Swedish National Food Agency, SE 75126 Uppsala, Sweden \\ ${ }^{2}$ Department of Public Health and Caring Sciences, Clinical Nutrition and Metabolism, Uppsala University, Uppsala, Sweden \\ ${ }^{3}$ Department of Medical Sciences, Clinical Chemistry, Uppsala University, Uppsala, Sweden \\ ${ }^{4}$ Department of Internal Medicine and Clinical Nutrition, University of Gothenburg, Gothenburg, Sweden
}

(Received 6 January 2020 - Final revision received 13 August 2020 - Accepted 4 September 2020)

Journal of Nutritional Science (2020), vol. 9, e47, page 1 of 11

doi:10.1017/jns. 2020.40

Abstract

The study aimed to estimate vitamin D intake and plasma/serum 25-hydroxyvitamin D (25(OH)D) concentrations, investigate determinants of 25(OH)D concentrations and compare two $25(\mathrm{OH}) \mathrm{D}$ assays. We conducted two nationwide cross-sectional studies in Sweden with 206 school children aged $10-12$ years and 1797 adults aged 18-80 years ( $n 268$ provided blood samples). A web-based dietary record was used to assess dietary intake. Plasma/serum 25 $(\mathrm{OH}) \mathrm{D}$ was analysed by liquid chromatography-mass spectrometry (LC-MS) and immunoassay in adults and LC-MS/MS in children. Most participants reported a vitamin D intake below the average requirement (AR), $16 \%$ of children and $33 \%$ of adults met the AR (7.5 $\mu \mathrm{g})$. In adults, plasma 25 $(\mathrm{OH}) \mathrm{D}$ below 30 and $50 \mathrm{nmol} / 1$ were found in 1 and $18 \%$ of participants during the summer period and in 9 and $40 \%$ of participants during the winter period, respectively. In children, serum 25(OH)D below 30 and $50 \mathrm{nmol} / 1$ were found in 5 and $42 \%$ of participants (samples collected March-May), respectively. Higher $25(\mathrm{OH}) \mathrm{D}$ concentrations were associated with the summer season, vacations in sunny locations (adults), and dietary intake of vitamin $\mathrm{D}$ and use of vitamin D supplements, while lower concentrations were associated with a higher BMI and an origin outside of Europe. Concentrations of 25 $(\mathrm{OH}) \mathrm{D}$ were lower using the immunoassay than with the LC-MS assay, but associations with dietary factors and seasonal variability were similar. In conclusion, vitamin $\mathrm{D}$ intake was lower than the AR, especially in children. The $25(\mathrm{OH}) \mathrm{D}$ concentrations were low in many participants, but few participants had a concentration below $30 \mathrm{nmol} / \mathrm{l}$.

Key words: 25-hydroxyvitamin D: 25(OH)D assays: Adults: Children: Vitamin D status

\section{Introduction}

A low level of vitamin D (25-hydroxyvitamin D, 25(OH)D) in plasma or serum is a risk factor for the development of rickets in children ${ }^{(1)}$ and osteomalacia in adults ${ }^{(2)}$. Moreover, low levels of vitamin $\mathrm{D}$ have been associated with an increased risk of non-skeletal diseases ${ }^{(3-6)}$, such as cardiovascular diseases, cancer, autoimmune diseases and infectious diseases, and overall mortality. Vitamin D receptors are found in several cell types, indicating that an association may exist between vitamin D status and many diseases ${ }^{(7)}$.

Abbreviations: 25(OH)D: 25-hydroxyvitamin D; AR: average requirement; DEQAS: Vitamin D External Quality Assessment Scheme; LI: lower intake level; NNR 2012: Nordic Nutrition Recommendations 2012; OEMC: Occupational and Environmental Medicine Centers; RI: recommended intake; UL: upper intake level; UVB: ultraviolet B

* Corresponding author: Cecilia Nälsén, email cecilia.nalsen@slv.se

(C) The Author(s), 2020. Published by Cambridge University Press on behalf of The Nutrition Society. This is an Open Access article, distributed under the terms of the Creative Commons Attribution-NonCommercial-NoDerivatives licence (http://creativecommons.org/licenses/by-nc-nd/4.0/), which permits non-commercial re-use, distribution, and reproduction in any medium, provided the original work is unaltered and is properly cited. The written permission of Cambridge University Press must be obtained for commercial re-use or in order to create a derivative work. 
The most important determinant of vitamin $\mathrm{D}$ status in most humans is skin synthesis of vitamin $\mathrm{D}^{(8)}$. For humans with no or limited sun exposure and those who reside in countries at latitudes higher than $42^{\circ} \mathrm{N}$, dietary intake of vitamin $\mathrm{D}$ is critical for maintaining healthy vitamin $\mathrm{D}$ levels ${ }^{(9)}$. Vitamin $\mathrm{D}_{3}$ is synthesised in the skin in the presence of ultraviolet $B$ (UVB) radiation ${ }^{(10)}$. In Nordic countries at latitudes $55-72^{\circ}$ $\mathrm{N}$, no vitamin $\mathrm{D}_{3}$ is synthesised in the skin during the late autumn, winter months and early spring (November-April) since the UVB radiation level is too low to induce cutaneous vitamin $\mathrm{D}_{3}$ production ${ }^{(11)}$.

Few foods are naturally rich in vitamin D, but in Sweden, certain products, including milk, fermented milk, yoghurt and fat spreads, are fortified with vitamin D (some mandatorily and other voluntarily). The major contributors to vitamin $\mathrm{D}$ intake in the Swedish adult population are fish (32\%), spreads $(14 \%)$, dairy products $(12 \%)$, meat $(8 \%)$, pastries $(5 \%)$, chicken $(4 \%)$ and eggs $(4 \%)^{(12)}$. The major contributors to vitamin $\mathrm{D}$ intake in the Swedish child population are dairy products $(25 \%)$, spreads (17-18\%), meat and chicken (14-17 $\%)$, fish $(11 \%)$ and pastries $(5 \%)^{(13)}$.

The concentrations of $25(\mathrm{OH}) \mathrm{D}$ in plasma or serum are commonly used to assess vitamin $\mathrm{D}$ status. Both vitamin $\mathrm{D}$ synthesis in the skin and vitamin D intake from foods and supplements are considered when measuring $25(\mathrm{OH}) \mathrm{D}$ concentrations. Several researchers have suggested that a 25 $(\mathrm{OH}) \mathrm{D}$ concentration above $50 \mathrm{nmol} / 1$ is optimal based on studies showing an increased risk of non-skeletal diseases at concentrations of $25(\mathrm{OH}) \mathrm{D}$ below $50 \mathrm{nmol} / \mathrm{1}^{(3,4,14)}$, while other researchers have suggested that higher concentrations are optimal. A risk of $25(\mathrm{OH}) \mathrm{D}$ deficiency, as well as increased risks of rickets and osteomalacia, is associated with concentrations below $30 \mathrm{nmol} / 1$. The Institute of Medicine (IOM) noted that $25(\mathrm{OH}) \mathrm{D}$ concentrations in plasma or serum above $75 \mathrm{nmol} / \mathrm{l}$ are not consistently associated with increased benefits and that 'there may be the reason for concern at concentrations above $125 \mathrm{nmol} / \mathrm{l}^{\text {(4) }}$. Furthermore, very high vitamin $\mathrm{D}$ intake can have toxic effects and can lead to hypercalcaemia and kidney failure, as well as other conditions ${ }^{(6)}$. Several methods have been used to measure $25(\mathrm{OH}) \mathrm{D}$ concentrations in plasma or serum $^{(15-17)}$. The most commonly applied methods are liquid chromatography (LC)-based methods with UV or mass spectrometric (MS)-detection and immunoassays ${ }^{(4,6)}$. Various methods used in different laboratories have produced different results, complicating the interpretation and comparison of results from different studies ${ }^{(18-20)}$. However, the assays have been improved using external controls and standardisation programme has been developed ${ }^{(21,22)}$. There have been differences between immunoassays and LC-MS/MS (lower values for immunoassays), but these differences have decreased over time the last decade. Recent comparisons of immunoassays vs. LC-MS/MS have shown that there were no consistent differences in the levels between the two methods; however, the immunoassays had a higher $\mathrm{CV} \%{ }^{(23)}$. Despite much interest in vitamin $\mathrm{D}$, there are few published data on vitamin D status from the Nordic countries, especially in children.
The aims of the present study were to estimate dietary intake of vitamin $\mathrm{D}$ and plasma or serum $25(\mathrm{OH}) \mathrm{D}$ concentrations in children and adults who participated in two nationwide cross-sectional studies in Sweden. In addition, the associations among $25(\mathrm{OH}) \mathrm{D}$ concentrations and dietary, lifestyle and demographic factors were investigated, and two assays used to measure $25(\mathrm{OH}) \mathrm{D}$ concentrations were compared.

\section{Materials and methods}

\section{Population and study design}

The results are based on two cross-sectional studies in Sweden. One study included adults, and one study included school children. Both studies were performed by the Swedish National Food Agency (NFA).

Adults. A national dietary survey, i.e. the 'Riksmaten adults 2010-11', was conducted between May 2010 and July 2011 and included participants aged 18-80 years from all regions in Sweden ${ }^{(12)}$.

The Riksmaten sample was divided into a diet only sample (n 3995) and a biomonitoring subsample (n 1008). All subjects were requested to record their diet and complete a questionnaire, while the subjects in the subsample were also asked to provide blood and urine samples. Sample selection was performed by Statistics Sweden, and the data from the Total Population Register in Sweden were intended to represent the Swedish adult population. The main sample was stratified by sex, age group and region, but the subsample was not stratified due to logistics and sample handling (see below). The participants were contacted by interviewers from Statistics Sweden on behalf of the NFA.

Blood sampling was carried out by seven Occupational and Environmental Medicine Centers (OEMCs) covering all regions in Sweden. From each centre, the regional capital (Umeå, Uppsala, Stockholm, Örebro, Linköping, Gothenburg and Lund) was selected. In addition, two smaller municipalities were randomly selected. Then, 48 individuals per municipality (144 individuals per centre) were randomly selected; thus, an equal number of individuals were randomly selected from each centre independently of its population size. The collection period for the subsample was divided into the following four periods: May/June 2010; August/September 2010; January/ February 2011; April/May 2011.

A total of $1497(37 \%)$ adults participated in the diet only part of the study, and $300(30 \%)$ adults participated in the biomonitoring part. For all analyses, except the blood analyses, the diet only and biomonitoring samples were combined (main study). The biomonitoring subsample included 268 participants with complete dietary records and questionnaires, and their $25(\mathrm{OH}) \mathrm{D}$ concentrations were measured using two assays.

School children. A study involving school children aged 1012 years was conducted between March and May 2014. The original focus of this study was to examine exposure to 
environmental contaminants and the data collections were, therefore, not spread out over the year. Children were in the 5th grade in schools in Umeå, Uppsala, Stockholm, Örebro, Linköping and Lund (all larger cities).

Ten schools per city with at least 25 individuals per class in the 5th grade were selected by Statistics Sweden; of these schools, the two largest schools per city were selected. Overall, 524 children were asked to participate in the study, and $262(50 \%)$ children participated in the study. All children were requested to provide dietary records, complete a questionnaire and provide blood and urine samples; the samples were collected by staff from the NFA and OEMCs by visiting the schools. Thus, 206 children with complete dietary records and questionnaire were included in the study, and their 25 $(\mathrm{OH}) \mathrm{D}$ concentrations were analysed.

\section{Ethics of human subject participation}

This study was conducted according to the guidelines laid down in the Declaration of Helsinki, and all procedures involving human subjects were approved by the Regional Ethical Review Board of Uppsala (reference number 2010/ 060 for adults and 2372/2013 for children). Written (from children and their parents) or verbal (from adults) informed consent was obtained from all subjects. Verbal consent was witnessed and formally recorded.

\section{Dietary assessment}

The participants were requested to record their intake of all foods and beverages over four consecutive days (including at least one weekend day) using a validated web-based dietary record $^{(24,25)}$. Quantities were reported in household measurements, numbers or portion sizes, as shown in photos. In addition, adults reported their use of food supplements in the dietary record, and children reported their use of food supplements in the questionnaire. In adults, intake of vitamin D from supplements was calculated using typical dosages of products on the market. In children, the intake of vitamin D from supplements was not calculated. The web-based dietary record is linked to the NFA's food composition database (version Riksmaten adults 2010-11). The content of 25-hydroxyvitamin $\mathrm{D}$ in food was not included in the database.

Reported dietary intake of vitamin D (intake from supplements is not included in the calculation) was compared with the dietary reference values in the Nordic Nutrition Recommendations 2012 (NNR 2012) ${ }^{(5)}$. The estimated average requirement (AR) of vitamin $\mathrm{D}$ is $7.5 \mu \mathrm{g} / \mathrm{d}$, with a lower intake level (LI) of $2.5 \mu \mathrm{g} / \mathrm{d}$ and an upper intake level (UL) of $100 \mu \mathrm{g} / \mathrm{d}$. The recommended intake (RI) for children older than 2 years and adults is $10 \mu \mathrm{g} / \mathrm{d}$, and the RI for elderly persons (i.e. $\geq 75$ years) is $20 \mu \mathrm{g} / \mathrm{d}$. The AR is a primary reference value used to assess the nutrient intakes, and RI, LI and UL can be used as complement reference values. In the NNR, the AR is defined as the intake of a nutrient that is sufficient to cover the requirement for half of a defined group. Intakes below the AR value are associated with a considerable probability of not meeting the requirement. The AR corresponds to the Estimated Average Requirement (EAR) used in the UK and US recommendations. RI is set to also covers individual variations and is, therefore, greater than the AR to cover the requirements in $97-98 \%$ of the individuals. Intake below the LI indicates an increased risk of deficiency in most individuals, while intake above the UL indicates the maximum long-term intake that is unlikely to cause a risk of adverse health effects.

Under-reporting was estimated according to Black ${ }^{(26)}$ using the ratio of energy expenditure to the basal metabolic rate (EI/ BMR), and body weight (BW) and physical activity levels (PALs) were also considered. Probable under-reporters (lowenergy reporters) were defined as those with an EI/BMR below $0 \cdot 93$.

\section{Blood sampling}

Blood samples were drawn from the antecubital region without an overnight fast. Blood was collected into serum tubes or tubes containing EDTA. After centrifugation, the plasma and serum aliquots were frozen at $-20^{\circ} \mathrm{C}$ until use.

\section{Measurement of vitamin D in plasma and serum}

Adults. Plasma 25(OH)D concentrations were determined using both an LC-MS assay and an immunoassay.

LC-MS assay. Plasma $25(\mathrm{OH}) \mathrm{D}_{3}$ and $25(\mathrm{OH}) \mathrm{D}_{2}$ concentrations were analysed separately using HPLC atmospheric pressure chemical ionisation mass spectrometry. HPLC was performed using a Hewlett-Packard 1100 liquid chromatograph (Agilent Technologies, Palo Alta, CA, USA), which was interfaced using atmospheric pressure chemical ionisation to a Hewlett-Packard mass spectrometer operated in single-ion monitoring mode at Vitas Analytical Services, Oslo, Norway ${ }^{(27)}$. The laboratory is GMP certified and participates in external control programmes, including the Vitamin D External Quality Assessment Scheme (DEQAS).

Chemiluminescence immunoassay. Total plasma 25(OH)D concentrations, including both $25(\mathrm{OH}) \mathrm{D}_{3}$ and $25(\mathrm{OH}) \mathrm{D}_{2}$, were measured using a chemiluminescence immunoassay (LIAISON 25(OH)D Assay (DiaSorin)) at the Department of Clinical Chemistry at Uppsala University Hospital, Sweden. This laboratory is accredited according to SS-EN-ISO/IEC 15189. As a part of the accreditation procedures, the laboratory participates in interlaboratory external proficiency testing schemes, which are conducted by LabQuality, Finland.

School children. Serum $25(\mathrm{OH}) \mathrm{D}_{3}$ concentrations were measured using an LC-MS/MS assay at OEMC, Lund, Sweden ${ }^{(28)}$. The analyses were conducted using a triple quadrupole linear ion trap mass spectrometer (QTRAP 5500; AB Sciex, Foster City, CA, USA) coupled to an LC system (UFLCXR, Shimadzu Corporation, Kyoto, Japan; 
LC/MS/MS). 25(OH) $\mathrm{D}_{3}$ concentrations were determined using a modified method for the analysis of perfluorinated compounds ${ }^{(29)}$. The laboratory participates in DEQAS, and control samples were checked against controls from Chromsystems Instruments \& Chemicals $\mathrm{GmbH}$ (MassCheck1; Gräfelfing, Germany).

Definition of winter and summer values. In Northern Europe, the UVB radiation level is too low to induce cutaneous vitamin $\mathrm{D}_{3}$ production during winter months ${ }^{(11)}$. Vitamin $\mathrm{D}$ is stored in adipose tissue and other tissues and thus some of the summer's vitamin D production is reflected in blood drawn in September and October. Therefore, the winter values were defined as values obtained with blood drawn between November and April, and the summer values were defined as values obtained with blood drawn between May and October, which also have been used in similar previous studies ${ }^{(30)}$.

\section{Other measurements}

The body mass index (BMI) was calculated as BW divided by height squared $\left(\mathrm{kg} / \mathrm{m}^{2}\right)$. In children, the age-specific BMI, i.e. the isoBMI, was also calculated to define normal (or low) BW (BMI <24.9), overweight (BMI 25-29.9) and obese (BMI $>30$ ) in a manner similar to that in which the terms are defined in adults ${ }^{(31)}$. BW and height were self-reported by adults and measured by OEMCs for children. The participants also completed a questionnaire with approximately 50 questions on foods that they rarely eat, sun exposure behaviour (adults), vacations in a sunny location, family size, smoking habits (adults) and other background or lifestyle factors.

\section{Statistical analysis}

The values are expressed as the median or mean and standard deviation (SD). A $P$ value $<0.05$ was considered significant, and tests were two-tailed. For variables with a skewed distribution (Shapiro Wilk's W test $<0.95$ ), a logarithmic or a square root transformation was performed before the statistical analysis. ANOVA or Student's unpaired $t$ test was used to analyse the differences between groups of different variables. Chi-square tests were performed to compare the proportions of the 25(OH)D concentrations below 30 and $50 \mathrm{nmol} / \mathrm{l}$. Pearson correlation coefficients were used to test the correlations among the variables. Multiple regression analysis was performed to identify the determinants of plasma $25(\mathrm{OH}) \mathrm{D}$ concentrations, and Bland-Altman analysis was used to evaluate the agreement between the LC-MS assay and the immunoassay. The statistical analyses were conducted using Stata version 12.1 (Stata Corp, College Station, TX, USA).

\section{Results}

\section{Characteristics of the study participants}

The characteristics of the study participants are summarised in Table 1. The characteristics of the two adult study samples were similar. More children than adults were born outside Europe.

\section{Intake of vitamin D from diet and use of supplements}

Adults. The mean (SD) daily intake of vitamin $\mathrm{D}$ from diet in the 1797 participants was $7 \cdot 0(4 \cdot 8) \mu \mathrm{g}$, as shown in Table 1 , with a median of $5.7 \mu \mathrm{g}$. Intake of vitamin $\mathrm{D}$ was higher in participants $\geq 75$ years than in younger participants (see Supplementary material). The results were similar after the under-reporters were excluded.

Dietary intake of vitamin $\mathrm{D}$ was associated with age before $(r 0 \cdot 267, P<0 \cdot 0001)$ and after adjusting for total energy intake $(r 0 \cdot 186, P<0 \cdot 0001)$.

In participants who reported use of vitamin D supplements on one or more days during the 4-day record ( $n 137)$, the mean (SD) daily intake of vitamin D from supplements was 6.9 (9.9) $\mu \mathrm{g}$ (median: $5 \mu \mathrm{g}$ ), and that from both diet and food supplements was 15.1 (11.6) $\mu \mathrm{g}$ (median: $12.9 \mu \mathrm{g}$ ). The mean daily intake from vitamin D supplements varied between 0.9 and $100 \mu \mathrm{g}$.

Dietary intake of vitamin D in participants ( $n$ 268) whose plasma $25(\mathrm{OH}) \mathrm{D}$ were also analysed was similar to that in the larger sample. The mean (SD) daily intake of vitamin D in the 268 participants was $7 \cdot 3(4 \cdot 6) \mu \mathrm{g}$, as shown in Table 1 , with a median of $6 \cdot 0 \mu \mathrm{g}$. In participants who reported use of vitamin D supplements (n 20), the mean (SD) daily intake of vitamin D from the supplements was $6.9(5 \cdot 1) \mu \mathrm{g}$ (median: $5 \mu \mathrm{g}$ ), and that from both diet and food supplements was $15.3(7 \cdot 4) \mu \mathrm{g}$ (median: $14.4 \mu \mathrm{g}$ ).

School children. The mean (SD) daily intake of vitamin D from diet in children $(n$ 206) was $5.3(3.0) \mu \mathrm{g}$, as shown in Table 1, with a median of $4.8 \mu \mathrm{g}$. In children, 15 participants reported use of vitamin D supplements, but the dosage of vitamin D from the supplements was not reported.

\section{Comparisons with NNR dietary reference values}

Adults. A total of $33 \%(n 593)$ of participants $(n 1797)$ met the AR (vitamin D intake $>7.5 \mu \mathrm{g} / \mathrm{d}$ ) ${ }^{(5)}$, while $9 \%(n 170)$ of participants reported intakes below the LI $(<2.5 \mu \mathrm{g} / \mathrm{d})$. Overall, $19 \%$ of participants met the RI $(>10 \mu \mathrm{g} / \mathrm{d})$. Intake of vitamin D from supplements was not included in the calculation. The results were similar after the under-reporters were excluded. None of the participants had vitamin D intakes from diet that were above the UL $(100 \mu \mathrm{g} / \mathrm{d})$, while one participant had an intake above the UL after including the vitamin $\mathrm{D}$ intake from supplements.

In the subsample $(n 268)$ whose $25(\mathrm{OH}) \mathrm{D}$ was analysed, 37 $\%$ met the AR, $7 \%$ reported an intake below the LI and $23 \%$ met the RI.

School children. A total of $16 \%(n 32)$ of participants $(n 206)$ met the AR $(7.5 \mu \mathrm{g} / \mathrm{d})$, while $14 \%(n 28)$ of the participants had an intake below the LI $(2.5 \mu \mathrm{g} / \mathrm{d})$. Overall, $5.5 \%(n 11)$ of participants met the RI cut-off of $10 \mu \mathrm{g} / \mathrm{d}$ or above. 
Table 1. Characteristics of the participants in the two cross-sectional studies with adults and children

\begin{tabular}{|c|c|c|c|c|c|c|c|c|c|}
\hline & \multicolumn{6}{|c|}{ Adults } & \multirow{2}{*}{\multicolumn{3}{|c|}{$\begin{array}{c}\text { Children } \\
n 206\end{array}$}} \\
\hline & \multicolumn{3}{|c|}{$n 268^{a}$} & \multicolumn{3}{|c|}{ n 1797} & & & \\
\hline & $\begin{array}{l}\text { Mean/ } \\
\text { proportion }\end{array}$ & SD & Range & $\begin{array}{l}\text { Mean/ } \\
\text { proportion }\end{array}$ & $\mathrm{SD}$ & Range & $\begin{array}{l}\text { Mean/ } \\
\text { proportion }\end{array}$ & SD & Range \\
\hline Gender (females/males) $(\%(n))$ & $54 / 46(144 / 124)$ & & & $56 / 44(1005 / 792)$ & & & $45 / 55(92 / 114)$ & & \\
\hline Age (years) & $50 \cdot 1$ & $16 \cdot 8$ & $19-80$ & 48.0 & 17 & $18-80$ & $11 \cdot 3^{\mathrm{b}}$ & 0.5 & $10-12$ \\
\hline $\mathrm{BMI}\left(\mathrm{kg} / \mathrm{m}^{2}\right)$ & $25 \cdot 5$ & $4 \cdot 0$ & $17 \cdot 5-45 \cdot 9$ & $25 \cdot 5$ & $4 \cdot 3$ & $16 \cdot 7-47 \cdot 5$ & $18 \cdot 6$ & 2.9 & $13 \cdot 4-29 \cdot 1$ \\
\hline Females & $25 \cdot 3$ & $4 \cdot 6$ & $17 \cdot 5-45 \cdot 9$ & $25 \cdot 0$ & $4 \cdot 6$ & $16 \cdot 7-45 \cdot 9$ & $18 \cdot 57$ & $3 \cdot 1$ & $13 \cdot 4-29 \cdot 1$ \\
\hline Males & $25 \cdot 7$ & $3 \cdot 2$ & $19 \cdot 0-35 \cdot 5$ & $26 \cdot 1$ & $3 \cdot 8$ & $18 \cdot 5-47.5$ & $18 \cdot 62$ & $2 \cdot 8$ & $14 \cdot 4-28 \cdot 2$ \\
\hline Education (\%) & & & & & & & - & & \\
\hline$\leq 9$ years & 10 & & & 14 & & & & & \\
\hline 10-12 years & 46 & & & 42 & & & & & \\
\hline$>12$ years & 44 & & & 44 & & & & & \\
\hline \multicolumn{10}{|l|}{ Region (\%) } \\
\hline North Sweden & 14 & & & 13 & & & 17 & & \\
\hline Middle Sweden & 43 & & & 41 & & & 60 & & \\
\hline South Sweden & 43 & & & 46 & & & 22 & & \\
\hline Born outside Europe (\% $(n))$ & $3.0(8)$ & & & $3 \cdot 1(55)$ & & & $14 \cdot 6(30)$ & & \\
\hline Females & $1.4(2)$ & & & $2 \cdot 8(28)$ & & & $16 \cdot 3(15)$ & & \\
\hline Males & $4.8(6)$ & & & $3.4(27)$ & & & $13 \cdot 2(15)$ & & \\
\hline Dietary intake of vitamin $D(\mu \mathrm{g} / \mathrm{d})$ & $7 \cdot 3$ & $4 \cdot 6$ & $1 \cdot 3-24 \cdot 1$ & 7.0 & $4 \cdot 8$ & $0.3-44.7$ & 5.3 & $3 \cdot 0$ & $0 \cdot 6-23 \cdot 1$ \\
\hline Females & $6 \cdot 4$ & $4 \cdot 1$ & $1 \cdot 3-20 \cdot 3$ & $6 \cdot 4$ & $4 \cdot 2$ & $0 \cdot 3-34 \cdot 0$ & $4 \cdot 7$ & $2 \cdot 3$ & $0 \cdot 6-15 \cdot 3$ \\
\hline Males & $8 \cdot 4$ & $4 \cdot 8$ & $1 \cdot 5-24 \cdot 1$ & $7 \cdot 6$ & $5 \cdot 4$ & $0.3-44.7$ & $5 \cdot 8$ & 3.4 & $0 \cdot 6-23 \cdot 1$ \\
\hline$P$ value & $<0.0001$ & & & 0.001 & & & 0.008 & & \\
\hline Dietary intake of vitamin $D(\mu \mathrm{g} / 10 \mathrm{MJ})$ & $8 \cdot 6$ & $5 \cdot 0$ & $1 \cdot 7-25 \cdot 3$ & $8 \cdot 6$ & $5 \cdot 5$ & $0.3-48 \cdot 2$ & $7 \cdot 4$ & $4 \cdot 0$ & $1 \cdot 2-28 \cdot 6$ \\
\hline Females & $8 \cdot 3$ & $5 \cdot 0$ & $1 \cdot 8-25 \cdot 3$ & $8 \cdot 8$ & $5 \cdot 4$ & $0.6-37 \cdot 6$ & $6 \cdot 6$ & $2 \cdot 8$ & $1 \cdot 2-15 \cdot 4$ \\
\hline Males & $9 \cdot 0$ & $5 \cdot 0$ & $1 \cdot 7-25 \cdot 3$ & $8 \cdot 3$ & $5 \cdot 6$ & $0.3-48 \cdot 2$ & $8 \cdot 1$ & 4.7 & $1 \cdot 9-28 \cdot 6$ \\
\hline$P$ value & 0.221 & & & 0.112 & & & 0.008 & & \\
\hline Use of vitamin D supplements $(\%(n))$ & $7.5(20)$ & & & $7 \cdot 6(137)$ & & & $7 \cdot 3(15)$ & & \\
\hline Season of blood sampling & & & & - & & & & & \\
\hline Summer $(n)$ & 210 & & & & & & 105 & & \\
\hline Winter $(n)$ & 58 & & & & & & 101 & & \\
\hline Smokers (\%) ${ }^{\mathrm{c}}$ & 14.5 & & & 14.9 & & & 0 & & \\
\hline
\end{tabular}

${ }^{a}$ In the biomonitoring subsample were $25(\mathrm{OH}) \mathrm{D}$ concentrations in plasma measured.

${ }^{b}$ Grade 5 in elementary school.

${ }^{\mathrm{C}}$ Smoking daily or occasionally.

Intake of vitamin D from supplements was not included in the calculation.

\section{Plasma/serum concentrations of 25-hydroxyvitamin D}

Adults. 25(OH)D concentrations as measured using an LC-MS assay: The mean (SD) plasma concentration of total $25(\mathrm{OH}) \mathrm{D}$ $\left(\mathrm{D}_{2}+\mathrm{D}_{3}\right)$ was $63.5(18 \cdot 2) \mathrm{nmol} / \mathrm{l}$ (Table 2). The mean plasma concentration of $25(\mathrm{OH}) \mathrm{D}_{3}$ was $63 \cdot 2(18 \cdot 2) \mathrm{nmol} / \mathrm{l}$, and $25(\mathrm{OH}) \mathrm{D}_{2}$ was detected in 15 subjects with a mean concentration of $4.9(2 \cdot 1) \mathrm{nmol} / 1.25(\mathrm{OH}) \mathrm{D}_{2}$ was detected in $8 \%(n 12)$ of female participants and $2 \%(n 3)$ of male participants with a concentration ranging between 3.0 and $10 \cdot 2 \mathrm{nmol} / \mathrm{l}$. Plasma 25(OH)D concentrations below 30 $\mathrm{nmol} / \mathrm{l}$ were found in $3 \%$ of participants, and concentrations below $50 \mathrm{nmol} / 1$ were found in $22 \%$ of participants. There were no differences in $25(\mathrm{OH}) \mathrm{D}$ levels between women and men. There were no differences in the mean $25(\mathrm{OH}) \mathrm{D}$ concentrations between the age groups, but the proportions below $30 \mathrm{nmol} / 1$ differed slightly ( $P$ O $0 \cdot 05$ ) between the age groups. A plasma $25(\mathrm{OH}) \mathrm{D}$ concentration above $125 \mathrm{nmol} / \mathrm{l}$ was found in one participant.

There was a seasonal variation in the plasma $25(\mathrm{OH}) \mathrm{D}$, as significantly higher concentrations were noted during the summer than during the winter. Moreover, proportions below 30 and $50 \mathrm{nmol} / 1$ were higher during the winter than during the summer (Table 2).

Demographic and lifestyle factors: Plasma 25(OH)D concentrations (measured with an LC-MS assay) stratified by demographic and lifestyle factors are presented in Table 3. A higher $25(\mathrm{OH}) \mathrm{D}$ concentration was associated with use of vitamin $\mathrm{D}$ supplements and vacations in sunny locations during the previous 2 months, while a lower $25(\mathrm{OH}) \mathrm{D}$ concentration was associated with a higher BMI, living in sparsely populated areas and small municipalities, being born outside Europe and living in a single household.

25(OH)D concentrations as measured using an immunoassay: The mean (SD) plasma total $25(\mathrm{OH}) \mathrm{D}$ concentration was 58.5 $(24 \cdot 5) \mathrm{nmol} / 1$ (see Supplementary Table S1). Plasma 25(OH) $\mathrm{D}$ concentrations below $30 \mathrm{nmol} / 1$ were found in $9 \%$ of participants, and those below $50 \mathrm{nmol} / 1$ were found in $39 \%$ of participants. There were no differences in $25(\mathrm{OH}) \mathrm{D}$ concentrations between women and men or between the age groups, as shown in Supplementary Table S1. Plasma 25(OH)D concentrations above $125 \mathrm{nmol} / 1$ were found in $1.5 \%(n 4)$ of participants.

The seasonal variations in plasma $25(\mathrm{OH}) \mathrm{D}$ concentrations, as determined using the immunoassay, were similar to those 
Table 2. Plasma levels of 25 -hydroxyvitamin $\mathrm{D}$, as determined using an LC-MS assay, in adults and the proportions of participants with levels below 30 and $50 \mathrm{nmol} / \mathrm{l}$

\begin{tabular}{|c|c|c|c|c|c|c|c|}
\hline & $n$ & Median P-25(OH)D (nmol/l) & Mean P-25(OH)D $(\mathrm{nmol} / \mathrm{l})$ & SD & Range & $\%(n)<30 \mathrm{nmol} / \mathrm{l}$ & $\%(n)<50 \mathrm{nmol} / \mathrm{l}$ \\
\hline Women and men & 268 & $62 \cdot 8$ & 63.5 & $18 \cdot 2$ & $20-168$ & $3.4(9)$ & $22.4(60)$ \\
\hline Women & 144 & $65 \cdot 1$ & $64 \cdot 6$ & $19 \cdot 3$ & $24-168$ & $4.9(7)$ & $20 \cdot 8(30)$ \\
\hline Men & 124 & $60 \cdot 3$ & $62 \cdot 2$ & $16 \cdot 8$ & 20-105 & $1 \cdot 6(2)$ & $24 \cdot 2(30)$ \\
\hline$P$ value & & & 0.265 & & & $0.156^{\mathrm{a}}$ & $0.511^{\mathrm{a}}$ \\
\hline \multicolumn{8}{|l|}{ Age groups } \\
\hline $18-30$ years & 44 & $66 \cdot 3$ & $65 \cdot 7$ & $24 \cdot 4$ & $20-168$ & $6 \cdot 8(3)$ & $18 \cdot 2(8)$ \\
\hline $31-44$ years & 62 & 63.0 & $62 \cdot 3$ & $15 \cdot 3$ & $30-95$ & 0 & $22 \cdot 6(14)$ \\
\hline $45-64$ years & 96 & $61 \cdot 6$ & $62 \cdot 2$ & $18 \cdot 8$ & $24-105$ & $5 \cdot 2(5)$ & $28 \cdot 1(27)$ \\
\hline $65-80$ years & 66 & 63.7 & $65 \cdot 0$ & $14 \cdot 7$ & $33-101$ & 0 & $16 \cdot 7(11)$ \\
\hline$P$ value & & & 0.606 & & & $0.050^{\mathrm{a}}$ & $0.319^{a}$ \\
\hline \multicolumn{8}{|l|}{ Season } \\
\hline Summer ${ }^{b}$ & 210 & 65.0 & $65 \cdot 7$ & 17.5 & $24-168$ & $1.4(3)$ & $17 \cdot 6(37)$ \\
\hline Winter ${ }^{c}$ & 58 & $55 \cdot 0$ & $55 \cdot 4$ & $18 \cdot 3$ & $20-94$ & $8 \cdot 6(5)$ & $39 \cdot 7(23)$ \\
\hline$P$ value & & & $<0.0001$ & & & $0.004^{a}$ & $<0.0001^{a}$ \\
\hline
\end{tabular}

P-25(OH)D, plasma 25-hydroxyvitamin D.

${ }^{a}$ Differences in the proportions of $25(\mathrm{OH}) \mathrm{D}$ concentrations below 30 or $50 \mathrm{nmol} / \mathrm{l}$

${ }^{\mathrm{b}}$ Summer values are defined as values obtained from blood samples collected in May-October.

${ }^{c}$ Winter values are defined as values obtained from blood samples collected in November-April.

measured using the LC-MS assay, i.e. they were $50 \cdot 4(26 \cdot 2)$ in the winter and $60 \cdot 7(23 \cdot 6) \mathrm{nmol} / \mathrm{l}$ in the summer $(P 0 \cdot 0002)$. The proportions of plasma $25(\mathrm{OH}) \mathrm{D}$ concentrations below 30 and $50 \mathrm{nmol} / 1$ were significantly higher during the winter (17\% and $54 \%$, respectively) than during the summer (6 and $41 \%$, respectively).

Plasma 25-bydroxyvitamin $D$ concentrations and dietary factors: The plasma $25(\mathrm{OH}) \mathrm{D}$ concentrations that were determined using the LC-MS assay and the immunoassay were both positively correlated with total dietary intake of vitamin $\mathrm{D}$, fish and vitamin D-fortified milk and milk products (see Supplementary Table S2).

Determinants of plasma 25(OH)D levels: According to the multiple regression analysis, the strongest determinants of $25(\mathrm{OH})$ $\mathrm{D}$ concentrations (measured using the LC-MS assay) were country of birth (born outside Europe was negative), vacationing in a sunny location (positive), season of blood sampling (winter was negative) and use of vitamin D supplements (positive). Furthermore, vitamin D intake and living in large municipalities were positively associated with plasma $25(\mathrm{OH}) \mathrm{D}$ levels, whereas BMI was negatively associated with plasma $25(\mathrm{OH}) \mathrm{D}$ levels. In addition, the regression model included age, education, household income, sun exposure behaviour, smoking habits, and family and residential region size, which were all non-significant factors in the model. This model explained $29 \%$ of the variability in the $25(\mathrm{OH}) \mathrm{D}$ concentrations (data not shown).

School children. The mean (SD) serum $25(\mathrm{OH}) \mathrm{D} \quad\left(\mathrm{D}_{3}\right)$ concentration was $52.9(14 \cdot 3) \mathrm{nmol} / \mathrm{l}$. Levels below 30 $\mathrm{nmol} / \mathrm{l}$ were found in $5 \%$ of participants, and levels below $50 \mathrm{nmol} / 1$ were found in $42 \%$ of participants, as shown in Table 4. There were no differences in $25(\mathrm{OH}) \mathrm{D}\left(\mathrm{D}_{3}\right)$ concentrations between girls and boys. The proportions below $50 \mathrm{nmol} / 1$ and, to a certain degree, the proportions below $30 \mathrm{nmol} / 1$ also differed among the included cities. There were no differences in the characteristics of the participants in the included cities, and the month of blood sampling did not explain the differences between the cities (data not shown). The proportions of serum 25(OH)D concentrations below $50 \mathrm{nmol} / \mathrm{l}$ were higher in March and April than in May (Table 4), but there was no difference in the mean serum $25(\mathrm{OH}) \mathrm{D}$ concentrations between MarchApril and May.

Demographic and lifestyle factors: Serum 25(OH)D concentrations stratified according to demographic and lifestyle factors are presented in Table 5. As was the case in adults, a higher $25(\mathrm{OH}) \mathrm{D}$ concentration in children was related to use of vitamin D supplements. In addition, a lower $25(\mathrm{OH}) \mathrm{D}$ concentration was related to a higher BMI and being born outside Europe (child and/or one or both parents). In contrast to $25(\mathrm{OH}) \mathrm{D}$ levels in adults, 25(OH)D levels in children did not differ between subjects who did and did not vacation in sunny locations during the previous 2 months.

\section{Comparisons of an LC-MS assay and a chemiluminescence immunoassay}

A lower mean $25(\mathrm{OH}) \mathrm{D}$ concentration was observed with the immunoassay than with the LC-MS assay (P 0.016 for the difference between methods), and the proportions below 30 and $50 \mathrm{nmol} / \mathrm{l}$ differed between the assays, as shown in Table 2 and Supplementary Table S1. The distribution of plasma 25 $(\mathrm{OH}) \mathrm{D}$ was wider when measured using the immunoassay than when measured using the LC-MS assay, as shown in Fig. 1, but there was an agreement between the two assays (see Supplementary Fig. S1).

\section{Discussion}

The results of this study showed that dietary intake of vitamin $\mathrm{D}$ was below the AR in most participants, especially in school children, according to the $\mathrm{NNR}^{(5)}$, and that $25(\mathrm{OH}) \mathrm{D}$ concentrations were low in many participants. Vitamin $\mathrm{D}$ intake and $25(\mathrm{OH}) \mathrm{D}$ levels were lower in children than in adults. The 
Table 3. Plasma concentrations of 25 -hydroxyvitamin D, as determined using an LC-MS assay, in adults according to demographic and lifestyle factors

\begin{tabular}{|c|c|c|c|c|}
\hline Variable & Mean P-25(OH)D (nmol/l) & SD & $P$ value & $P$ value adjusted ${ }^{a}$ \\
\hline Gender & & & 0.265 & 0.264 \\
\hline Women & $64 \cdot 6$ & $19 \cdot 3$ & & \\
\hline Men & $62 \cdot 2$ & $16 \cdot 8$ & & \\
\hline BMI & & & 0.018 & $0.026^{\mathrm{b}}$ \\
\hline$<24 \cdot 9, n 140$ & $66 \cdot 3$ & $18 \cdot 8$ & & \\
\hline 25-29.9, n 92 & $62 \cdot 1$ & $16 \cdot 4$ & & \\
\hline$>30, n 33$ & $57 \cdot 2$ & 17.5 & & \\
\hline Education & & & 0.320 & 0.186 \\
\hline$\leq 9$ years, $n 28$ & 59.5 & $16 \cdot 0$ & & \\
\hline 10-12 years, $n 122$ & $65 \cdot 0$ & $19 \cdot 3$ & & \\
\hline$>12$ years, $n 117$ & 62.9 & 17.5 & & \\
\hline Income of household ${ }^{c}$ & & & 0.082 & 0.055 \\
\hline Below median income, $n 133$ & $61 \cdot 7$ & $18 \cdot 7$ & & \\
\hline Above median income, $n 134$ & $65 \cdot 5$ & $17 \cdot 3$ & & \\
\hline Region & & & 0.288 & 0.633 \\
\hline North Sweden, $n 38$ & 59.5 & $14 \cdot 2$ & & \\
\hline Middle Sweden, $n 116$ & 63.5 & $20 \cdot 3$ & & \\
\hline South Sweden, $n 114$ & $64 \cdot 8$ & $16 \cdot 9$ & & \\
\hline Residential area & & & 0.004 & 0.008 \\
\hline Sparsely populated area and small municipalities, $n 78$ & $58 \cdot 6$ & $16 \cdot 4$ & & \\
\hline Large municipalities, $n 190$ & $65 \cdot 5$ & 18.5 & & \\
\hline Country of birth & & & $<0.0001$ & $<0.0001$ \\
\hline Europe, $n 260$ & $64 \cdot 3$ & $17 \cdot 7$ & & \\
\hline Outside Europe, $n 8$ & $36 \cdot 6$ & 11.5 & & \\
\hline Size of family & & & 0.046 & 0.030 \\
\hline 1 person, $n 54$ & $58 \cdot 3$ & $17 \cdot 4$ & & \\
\hline 2 persons, $n 117$ & $65 \cdot 4$ & $17 \cdot 0$ & & \\
\hline$>3$ persons, $n 95$ & $64 \cdot 7$ & $19 \cdot 1$ & & \\
\hline Family with children & & & 0.648 & 0.966 \\
\hline Yes, $n 85$ & 63.1 & 19.5 & & \\
\hline No, $n 167$ & $64 \cdot 2$ & $17 \cdot 2$ & & \\
\hline Use of vitamin D supplements & & & 0.049 & 0.026 \\
\hline Yes, $n 20$ & $71 \cdot 2$ & $28 \cdot 3$ & & \\
\hline No, $n 248$ & $62 \cdot 9$ & $17 \cdot 0$ & & \\
\hline Sun exposure behaviour & & & 0.515 & 0.981 \\
\hline Sun, $n 33$ & $66 \cdot 8$ & $18 \cdot 9$ & & \\
\hline Shade, $n 17$ & $62 \cdot 0$ & $32 \cdot 4$ & & \\
\hline Sun and shade, $n 216$ & $63 \cdot 1$ & $16 \cdot 6$ & & \\
\hline Vacation in a sunny location during the previous 2 months & & & 0.0001 & 0.0001 \\
\hline Yes, $n 29$ & $75 \cdot 4$ & 17.4 & & \\
\hline No, $n 238$ & $62 \cdot 0$ & 17.8 & & \\
\hline Smoking & & & 0.323 & 0.455 \\
\hline Never/stopped smoking, $n 226$ & 63.9 & 18.5 & & \\
\hline Daily/occasionally, $n 39$ & 60.7 & $16 \cdot 5$ & & \\
\hline
\end{tabular}

P-25(OH)D, plasma 25-hydroxyvitamin D.

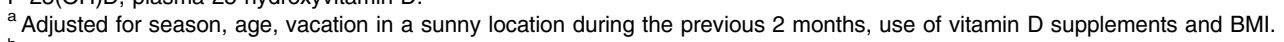

${ }^{\mathrm{b}}$ Adjusted for season, vacation in a sunny location during the previous 2 months and use of vitamin $\mathrm{D}$ supplements.

${ }^{\mathrm{c}}$ Analysis based on annual income.

Table 4. Serum levels of 25-hydroxyvitamin D, as determined using an LC-MS/MS assay, in children and the proportions of children with levels below 30 and $50 \mathrm{nmol} / \mathrm{l}$

\begin{tabular}{|c|c|c|c|c|c|c|c|}
\hline & $n$ & Median S-25(OH)D (nmol/l) & Mean S-25(OH)D (nmol/l) & SD & Range & $\%(n)<30 \mathrm{nmol} / \mathrm{l}$ & $\%(n)<50 \mathrm{nmol} / \mathrm{l}$ \\
\hline All children & 206 & $52 \cdot 0$ & $52 \cdot 9$ & $14 \cdot 3$ & $13-112$ & $4.9(10)$ & $42 \cdot 2(87)$ \\
\hline Girls & 92 & $51 \cdot 4$ & $50 \cdot 8$ & $14 \cdot 1$ & $23-112$ & $7.6(7)$ & $43.5(40)$ \\
\hline Boys & 114 & $52 \cdot 5$ & $54 \cdot 5$ & $14 \cdot 3$ & $13-98$ & $2 \cdot 6(3)$ & $41 \cdot 2(47)$ \\
\hline$P$ value & & & 0.064 & & & $0.098^{\mathrm{a}}$ & $0.745^{\mathrm{a}}$ \\
\hline \multicolumn{8}{|l|}{ Season } \\
\hline May & 105 & $53 \cdot 8$ & $53 \cdot 3$ & $14 \cdot 0$ & $13-94$ & $5 \cdot 7(6)$ & $35 \cdot 2(37)$ \\
\hline March-April & 101 & $50 \cdot 2$ & $52 \cdot 4$ & $14 \cdot 6$ & $23-112$ & $4.0(4)$ & $49.5(50)$ \\
\hline$P$ value & & & 0.646 & & & $0.558^{a}$ & $0.038^{a}$ \\
\hline
\end{tabular}

S-25(OH)D, serum 25-hydroxyvitamin D.

${ }^{a}$ Differences in the proportions of $25(\mathrm{OH}) \mathrm{D}$ concentrations below 30 or $50 \mathrm{nmol} / \mathrm{l}$. 
important determinants of $25(\mathrm{OH}) \mathrm{D}$ concentrations were vitamin D intake from food; use of vitamin D supplements; the season during which blood sampling was performed; origin outside Europe; vacationing in sunny locations (adults); and BMI. There was considerable individual variability with respect to $25(\mathrm{OH}) \mathrm{D}$ levels, a phenomenon that was only partially explained in this study.

\section{Intake of vitamin D from diet}

In recent years, several countries, including the Nordic countries, have increased the RI of vitamin $\mathrm{D}^{(5)}$. In this study, only $16 \%$ of children and $33 \%$ of adults (vitamin D supplements not included) met the AR $(7.5 \mu \mathrm{g} / \mathrm{d})$. This is of concern, that a high proportion of the population, and in particular in the child population, had vitamin $\mathrm{D}$ intakes below the recommendations. In children, vitamin D is important during the skeletal growth and mineralisation. Substantial variation in dietary intake of vitamin $\mathrm{D}$ among countries has been reported and the intake in many European countries is lower than that observed in our study ${ }^{(5,32-34)}$. The higher intakes in Sweden, other Nordic countries, the USA and Canada may reflect vitamin $\mathrm{D}$ fortification but also various eating habits in the countries. Furthermore, few foods are naturally rich in vitamin D. Results from Riksmaten adults 2010-11 have reported that the major contributors to vitamin $\mathrm{D}$ intake were fish, fortified spreads, milk and milk products ${ }^{(12)}$. Similar contributors were noted in a Swedish population of children; however, milk, milk products and fortified spreads were greater contributors than fish in children ${ }^{(13)}$.

In Sweden, an extended mandatory fortification of additional products with higher levels of vitamin $\mathrm{D}$ was recently implemented. The mandatory fortification includes an extended fortification of milk, fermented milk products and vegetable products replacing milk ( $\leq 3 \%$ fat), with a fortification level of $10 \mu \mathrm{g}$ vitamin $\mathrm{D} / \mathrm{l}$, and an extended fortification of spreads, with a fortification level of $20 \mu \mathrm{g}$ vitamin $\mathrm{D} / 100 \mathrm{~g}$. The extended mandatory fortification is expected to result in

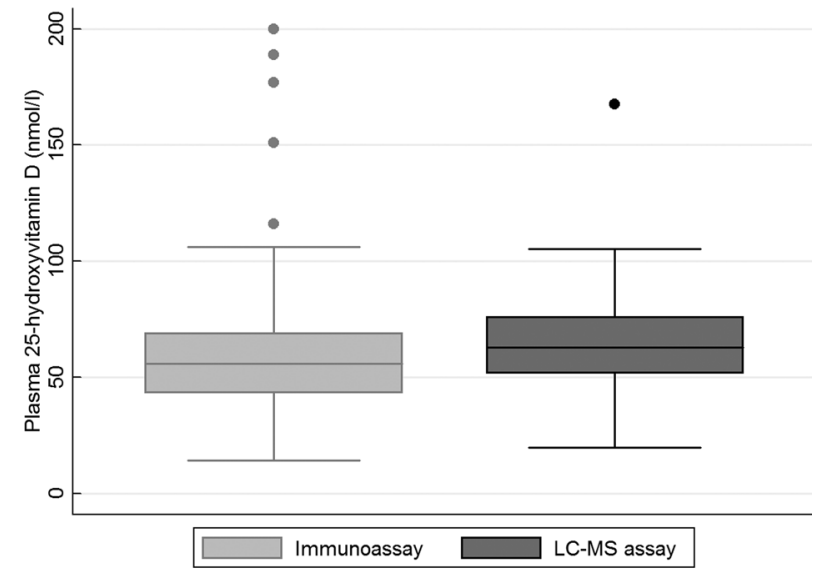

Fig. 1. Box plot of the distribution of plasma 25-hydroxyvitamin D, as determined using an immunoassay and an LC-MS assay in adults aged 18-80 years ( $n$ 268). The box plot is presented with whiskers with the maximum 1.5 interquartile range.

increased intake of vitamin D in the Swedish population, particularly in children with low fish intakes.

\section{Concentrations of 25-hydroxyvitamin D}

Few participants had $25(\mathrm{OH}) \mathrm{D}$ concentrations below 30 $\mathrm{nmol} / 1$ ( $5 \%$ of children and $3 \%$ of adults), which is often used to indicate a risk of deficiency. Our results showed that $18 \%$ of adults during the summer and $40 \%$ of adults during the winter had $25(\mathrm{OH}) \mathrm{D}$ concentrations below $50 \mathrm{nmol} / \mathrm{l}$, as measured using the LC-MS assay. Comparing the $25(\mathrm{OH}) \mathrm{D}$ concentrations from March to April in children with those from the winter months in adults showed that more children than adults had 25(OH)D levels below $50 \mathrm{nmol} / \mathrm{l}$, but more children than adults did not have levels below $30 \mathrm{nmol} / \mathrm{l}$. However, the study including the school children was not designed in the same way as the study including the adults, in which blood samples were collected throughout the year. Since the participation rate was low in the adult population

Table 5. Serum concentrations of 25-hydroxyvitamin D, as determined using an LC-MS/MS assay, in children according to demographic and lifestyle factors

\begin{tabular}{|c|c|c|c|c|}
\hline Variable & Mean S-25(OH)D (nmol/l) & SD & Unadjusted & $P$ value adjusted ${ }^{\mathrm{a}}$ \\
\hline BMI & & & 0.026 & $0.009^{b}$ \\
\hline <iso $24 \cdot 9, n 170$ & $54 \cdot 0$ & $14 \cdot 4$ & & \\
\hline iso $25-29 \cdot 9, n 29$ & $48 \cdot 8$ & $12 \cdot 6$ & & \\
\hline >iso $30, n 7$ & $42 \cdot 3$ & $12 \cdot 6$ & & \\
\hline Country of birth ${ }^{\mathrm{c}}$ & & & 0.004 & 0.0008 \\
\hline Europe, $n 176$ & $54 \cdot 0$ & $13 \cdot 4$ & & \\
\hline Outside Europe, $n 30$ & $46 \cdot 0$ & $17 \cdot 4$ & & \\
\hline Use of vitamin D supplements & & & 0.002 & 0.0015 \\
\hline Yes, $n 15$ & $63 \cdot 6$ & $20 \cdot 9$ & & \\
\hline No, $n 191$ & $52 \cdot 0$ & $13 \cdot 4$ & & \\
\hline Vacation in a sunny location during the previous 2 months & & & $0 \cdot 185$ & $0 \cdot 187$ \\
\hline Yes, $n 20$ & $57 \cdot 1$ & $20 \cdot 0$ & & \\
\hline No, $n 178$ & $52 \cdot 6$ & $13 \cdot 3$ & & \\
\hline
\end{tabular}

S-25(OH)D, serum 25-hydroxyvitamin D.

${ }^{a}$ Adjusted for season, vacation in sunny location during the previous 2 months, vitamin D supplements and BMI.

${ }^{\mathrm{b}}$ Adjusted for season, vacation in a sunny location during the previous 2 months and vitamin $\mathrm{D}$ supplements.

${ }^{\mathrm{c}}$ Born outside Europe includes children and/or one or both parents. 
(30\%), the adult participants may have had healthier lifestyles, as well as higher fish intake, than the children. Moreover, fewer participants than non-participants were born outside Europe. Thus, the adult participants in our study might have a better vitamin D status than most of the Swedish population. The participation rate in the child population was higher (50 $\%$ ); therefore, the child population might be more representative of the general population than the adult population. We do not think that the differences in $25(\mathrm{OH}) \mathrm{D}$ concentrations between children and adults are due to the analytical method. No considerable differences have been reported between LC-MS/MS and LC-MS assays. However, other investigators have also reported lower levels of $25(\mathrm{OH}) \mathrm{D}$ in girls aged 11-13 years than in elderly women aged 70-74 years ${ }^{(35)}$. Similar results or somewhat higher concentrations of 25 $(\mathrm{OH}) \mathrm{D}$ have been found in other studies in adults in Sweden ${ }^{(36-38)}$. There are few studies that cover the same age group in children as in our study, but in one Swedish regional study with children aged 8-9 years, similar results were reported $^{(39)}$.

The small number of participants in this study with $25(\mathrm{OH})$ $\mathrm{D}$ concentrations below $30 \mathrm{nmol} / 1$ may reflect the intake of fortified foods. In addition, in children, free school meals might also contribute to a higher intake of vitamin D, resulting in a better vitamin $\mathrm{D}$ status.

We did not observe differences in $25(\mathrm{OH}) \mathrm{D}$ concentrations between the age groups or between females and males. Similar findings were also found in a study involving 18 European studies $^{(40)}$.

\section{Determinants of 25-hydroxyvitamin D concentrations}

Sun exposure is an important factor in skin synthesis of vitamin D, and our results demonstrated that adult participants who had been on vacation in a sunny location had higher 25 $(\mathrm{OH}) \mathrm{D}$ concentrations than those who had not; these findings are consistent with those of other studies ${ }^{(41-43)}$. In children, vacationing in a sunny location was not related to $25(\mathrm{OH}) \mathrm{D}$ concentrations. This discrepancy between the child and adult populations might be due to children spending more time outdoors and a greater use of sunblock than adults and may also indicate that vacationing in a sunny location had a greater impact on vitamin D status in adults than in children. Despite the apparent absence of the influence of sun exposure behaviour on the results of the study, in adults, the seasonal variation in the mean $25(\mathrm{OH}) \mathrm{D}$ concentrations was approximately $10 \mathrm{nmol} / 1$. As expected, in children, the proportions of subjects with concentrations below $50 \mathrm{nmol} / 1$ were lower in May than in March-April, indicating that increases in UVB radiation exposure in May are sufficient to induce skin synthesis of vitamin $\mathrm{D}$. The seasonal variations reported in our study are consistent with those reported in numerous other studies ${ }^{(30,35,44-48)}$. There were no differences in plasma $25(\mathrm{OH}) \mathrm{D}$ concentrations among adults living in the north, middle or south of Sweden, which was unexpected since Sweden is a country with a shifting climate in the north compared to the south. Sweden is situated between latitude 55 and $69^{\circ} \mathrm{N}$, and from north to south, is greater than $1500 \mathrm{~km}$ long
(Lantmäteriet, The Swedish mapping, cadastral and land registration authority, personal communication). However, it is possible that our sample was too small and that we collected too few blood samples, particularly during the winter season. Furthermore, the results from another nationwide Swedish study showed that there were no differences in $25(\mathrm{OH}) \mathrm{D}$ concentrations according to the living region ${ }^{(49)}$.

In this study, we noted associations between intake of fish, vitamin $\mathrm{D}$-fortified milk and milk products, and vitamin $\mathrm{D}$ from diet and higher $25(\mathrm{OH}) \mathrm{D}$ levels. These findings may reflect that higher $25(\mathrm{OH}) \mathrm{D}$ concentrations are observed in adults than in children. Other studies have also reported associations between the intake of foods containing vitamin $\mathrm{D}$ or use of vitamin D supplements and the levels of $25(\mathrm{OH})$ $\mathrm{D}^{(1,50,51)}$. We found that approximately $30 \%$ of the total variation in plasma $25(\mathrm{OH}) \mathrm{D}$ concentrations were explained by the country of birth, vacationing in a sunny location, the season during which blood sampling was performed, use of vitamin D supplements, dietary vitamin D intake, living in large municipalities and BMI. Differences in the synthesis of 25 $(\mathrm{OH}) \mathrm{D}$ may also depend on genetics ${ }^{(52)}$, and further studies are required to clarify how the influence of genetics on vitamin D levels affects health.

\section{Comparisons of the LC-MS assay and the immunoassay}

Our results showed that the mean concentrations of $25(\mathrm{OH})$ $\mathrm{D}$, as measured using the immunoassay, were lower than those measured using the LC-MS assay. Furthermore, the proportions below 30 and $50 \mathrm{nmol} / 1$ were higher with the immunoassay than with the LC-MS assay. This result is consistent with those of other studies ${ }^{(18,53)}$. Several assays are used to measure $25(\mathrm{OH}) \mathrm{D}$ concentrations, and LC-MS-based methods are considered more accurate and reliable than immunoassays ${ }^{(4,5,18)}$. Furthermore, all assays have advantages and disadvantages, and improvements in the assays and standardisation of serum $25(\mathrm{OH}) \mathrm{D}$ data have been achieved $^{(21,22)}$. However, the seasonal variations and associations among plasma $25(\mathrm{OH}) \mathrm{D}$ and dietary factors were similar between the LS-MS assay and the immunoassay.

\section{Strengths and limitations}

The strengths of this study were that the selection of adults was based on data from the Total Population Register in Sweden, which represented the Swedish adult population aged 18-80 years in all regions in Sweden. Most studies in Sweden are regional studies, and nationwide studies are scarce. In addition, blood samples were collected from the adult subjects throughout the year, and the plasma 25(OH)D concentrations were measured using two assays. Detailed information regarding food and beverage intake was obtained using a web-based dietary record. Furthermore, for children, cities in all regions in Sweden were included in the study. One limitation of the study was the low response rate among adults, which might have led to a selection bias and resulted in the inclusion of participants with a healthier lifestyle; thus, the vitamin D status of the Swedish population is 
likely worsen than that presented in this study. The low response rate resulted in small groups and complicated the interpretation of our results. Furthermore, in children, blood samples were not collected throughout the year. The dietary record included only $4 \mathrm{~d}$, which might have been too short time to collect data reflecting typical vitamin D intake (particularly fish). Moreover, a limitation of this study was that the blood samples were collected at only one occasion for each participant.

\section{Conclusion}

In conclusion, the results of this study showed that the mean intake of vitamin $\mathrm{D}$ was lower than the $\mathrm{AR}$ in both children and adults; only $33 \%$ of adults and $16 \%$ of children met the AR. Concentrations of $25(\mathrm{OH}) \mathrm{D}$ were low in many participants, but few participants had concentrations below $30 \mathrm{nmol} / \mathrm{l}$. Vitamin D intake and $25(\mathrm{OH}) \mathrm{D}$ levels were lower in children than in adults. Future studies are needed to clarify how vitamin D status can be improved in different population groups. One way is the fortification of certain foods, which may be especially important for children.

\section{Supplementary material}

The supplementary material for this article can be found at https://doi.org/10.1017/jns.2020.40.

\section{Acknowledgements}

We thank all the participants, Ingalill Gadhasson (NFA; for sample handling), Rebecca Mosson (previously a master's student at NFA; for the calculation of the quantity of vitamin D from supplements) and Elin Dahlgren (for the fieldwork with the school children).

This work was partly supported by the Swedish Environmental Protection Agency and the Swedish Civil Contingencies Agency. The funders had no role in the design, analysis or writing of this article.

C.N. contributed to study design and data collection of the adult study and wrote the article. W.B. contributed to study design of the adult study. M.P. contributed to the data collection of the children and adult studies. P.R. contributed to study design of the blood sampling of the adult study. A.K. L. contributed to study design and data collection of the children and adult studies. N.K. contributed to study design and data collection of the children study. I.M. contributed to study design of the adult study. All authors contributed to interpretation of the data and revision of the article.

The authors declare no conflict of interest.

\section{References}

1. Cranney A, Horsley T, O'Donnell S, et al. (2007) Effectiveness and safety of vitamin D in relation to bone health. Evid Rep Tecbnol Assess (Full Rep) 158, 1-235.

2. Gifre L, Peris P, Monegal A, et al. (2011) Osteomalacia revisited: a report on 28 cases. Clin Rheumatol 30, 639-645.
3. EFSA NDA Panel (EFSA Panel on Dietetic Products, Nutrition and Allergies) (2016). Scientific opinion on dietary reference values for vitamin D. EFSA J 14, 4547, 145 pp. doi:10.2903/j. efsa.2016.4547.

4. IOM (2011) Dietary Reference Intakes for Calcium and Vitamin D. Washington, DC: The National Academies Press.

5. NCM (2014) Nordic Nutrition Recommendations 2012. Integrating Nutrition and Physical Activity. Copenhagen: Nordic Council of Ministers.

6. SACN (2016) Vitamin D and Health Report. SACN (Scientific Advisory Committee on Nutrition).

7. Bischoff-Ferrari H (2010) Health effects of vitamin D. Dermatol Ther 23, 23-30.

8. Holick MF, Chen TC, Lu Z, et al. (2007) Vitamin D and skin physiology: a D-lightful story. J Bone Miner Res 22, V28-33.

9. Engelsen $O$ (2010) The relationship between ultraviolet radiation exposure and vitamin D status. Nutrients 2, 482-495.

10. Holick MF (1995) Environmental factors that influence the cutaneous production of vitamin D. Am J Clin Nutr 61, 638S-645S.

11. Engelsen O, Brustad M, Aksnes L, et al. (2005) Daily duration of vitamin $\mathrm{D}$ synthesis in human skin with relation to latitude, total ozone, altitude, ground cover, aerosols and cloud thickness. Photochem Photobiol 81, 1287-1290.

12. NFA (2012) Riksmaten-Adults 2010-11. Food and Nutrient Intake among Adults in Sweden (in Swedish with English summary). Uppsala: NFA (Swedish National Food Agency).

13. Enghardt Barbieri H, Pearson M \& Becker W (2006) Riksmaten-Children 2003. Food and Nutrient Intake among Children in Sweden (in Swedish with English summary). Uppsala: National Food Agency.

14. Lamberg-Allardt C, Brustad M, Meyer HE, et al. (2013) Vitamin D - a systematic literature review for the 5 th edition of the Nordic Nutrition Recommendations. Food Nutr Res 57, 22671.

15. Wallace AM, Gibson S, de la Hunty A, et al. (2010) Measurement of 25-hydroxyvitamin $\mathrm{D}$ in the clinical laboratory: current procedures, performance characteristics and limitations. Steroids 75 , 477-488.

16. Volmer DA, Mendes LR \& Stokes CS (2015) Analysis of vitamin D metabolic markers by mass spectrometry: current techniques, limitations of the "gold standard" method, and anticipated future directions. Mass Spectrom Rev 34, 2-23.

17. Su Z, Narla SN \& Zhu Y (2014) 25-Hydroxyvitamin D: analysis and clinical application. Clin Chim Acta 433, 200-205.

18. Snellman G, Melhus H, Gedeborg R, et al. (2010) Determining vitamin D status: a comparison between commercially available assays. PLOS ONE 5, e11555.

19. Carter GD (2011) Accuracy of 25-hydroxyvitamin D assays: confronting the issues. Curr Drug Targets 12, 19-28.

20. Binkley N, Dawson-Hughes B, Durazo-Arvizu R, et al. (2017) Vitamin D measurement standardization: The way out of the chaos. J Steroid Biochem Mol Biol 173, 117-121.

21. Sempos CT, Vesper HW, Phinney KW, et al. (2012) Vitamin D status as an international issue: national surveys and the problem of standardization. Scand J Clin Lab Invest Suppl 243, 32-40.

22. Cashman KD, Kiely M, Kinsella M, et al. (2013) Evaluation of Vitamin D Standardization Program protocols for standardizing serum 25-hydroxyvitamin D data: a case study of the program's potential for national nutrition and health surveys. Am J Clin Nutr 97, 1235-1242.

23. Wise S, Phinney K, Tai S, et al. (2017) Baseline assessment of 25-hydroxyvitamin D assay performance: a vitamin D standardization program (VDSP) interlaboratory comparison study. $J A O A C$ Int 100, 1244-1252.

24. Warensjo Lemming E, Nalsen C, Becker W, et al. (2015) Relative validation of the dietary intake of fatty acids among adults in the Swedish National Dietary Survey using plasma phospholipid fatty acid composition. J Nutr $S_{c i} 4$, e25.

25. Nybacka S, Berteus Forslund H, Wirfalt E, et al. (2016) Comparison of a web-based food record tool and a food-frequency 
questionnaire and objective validation using the doubly labelled water technique in a Swedish middle-aged population. J Nutr $S_{c i}$ 5, e39.

26. Black AE (2000) Critical evaluation of energy intake using the Goldberg cut-off for energy intake:basal metabolic rate. A practical guide to its calculation, use and limitations. Int J Obes Relat Metab Disord 24, 1119-1130.

27. Meyer HE, Robsahm TE, Bjorge T, et al. (2013) Vitamin D, season, and risk of prostate cancer: a nested case-control study within Norwegian health studies. Am J Clin Nutr 97, 147-154.

28. Gustafsson P, Rylander L, Lindh CH, et al. (2015) Vitamin D status at birth and future risk of Attention Deficit/Hyperactivity Disorder (ADHD). PLOS ONE 10, e0140164.

29. Lindh CH, Rylander L, Toft G, et al. (2012) Blood serum concentrations of perfluorinated compounds in men from Greenlandic Inuit and European populations. Chemosphere 88, 1269-1275.

30. Snellman G, Melhus H, Gedeborg R, et al. (2009) Seasonal genetic influence on serum 25-hydroxyvitamin D levels: a twin study. PLoS ONE 4, e7747.

31. Cole TJ, Bellizzi MC, Flegal KM, et al. (2000) Establishing a standard definition for child overweight and obesity worldwide: international survey. BMJ 320, 1240-1243.

32. Spiro A \& Buttriss JL (2014) Vitamin D: an overview of vitamin D status and intake in Europe. Nutr Bull 39, 322-350.

33. Fulgoni VL 3rd, Keast DR, Bailey RL, et al. (2011) Foods, fortificants, and supplements: where do Americans get their nutrients? J Nutr 141, 1847-1854.

34. Vatanparast H, Calvo MS, Green TJ, et al. (2010) Despite mandatory fortification of staple foods, vitamin D intakes of Canadian children and adults are inadequate. I Steroid Biochem Mol Biol 121, 301-303.

35. Andersen R, Brot C, Jakobsen J, et al. (2013) Seasonal changes in vitamin D status among Danish adolescent girls and elderly women: the influence of sun exposure and vitamin D intake. Eur J Clin Nutr 67, 270-274.

36. Ramnemark A, Norberg M, Pettersson-Kymmer U, et al. (2015) Adequate vitamin $\mathrm{D}$ levels in a Swedish population living above latitude 63 degrees N: the 2009 Northern Sweden MONICA study. Int J Circumpolar Health 74, 27963.

37. Michaelsson K, Wolk A, Byberg L, et al. (2017) The seasonal importance of serum 25-hydroxyvitamin D for bone mineral density in older women. J Intern Med 281, 167-178.

38. Burgaz A, Akesson A, Oster A, et al. (2007) Associations of diet, supplement use, and ultraviolet $\mathrm{B}$ radiation exposure with vitamin $\mathrm{D}$ status in Swedish women during winter. Am J Clin Nutr 86, 1399-1404.

39. Videhult FK, Ohlund I, Hernell O, et al. (2016) Body mass but not vitamin $\mathrm{D}$ status is associated with bone mineral content and density in young school children in northern Sweden. Food Nutr Res 60, 30045 .
40. Cashman KD, Dowling KG, Skrabakova Z, et al. (2016) Vitamin D deficiency in Europe: pandemic? Am J Clin Nutr 103, 1033-1044.

41. Bjork A, Andersson A, Johansson G, et al. (2013) Evaluation of sun holiday, diet habits, origin and other factors as determinants of vitamin D status in Swedish primary health care patients: a crosssectional study with regression analysis of ethnic Swedish and immigrant women. BMC Fam Pract 14, 129.

42. Voipio AJ, Pahkala KA, Viikari JS, et al. (2015) Determinants of serum $25(\mathrm{OH}) \mathrm{D}$ concentration in young and middle-aged adults. The Cardiovascular Risk in Young Finns Study. Ann Med 47, 253-262.

43. Hedlund L, Brembeck P \& Olausson H (2013) Determinants of vitamin $\mathrm{D}$ status in fair-skinned women of childbearing age at northern latitudes. PLoS ONE 8, e60864.

44. Klingberg E, Olerod G, Konar J, et al. (2015) Seasonal variations in serum 25-hydroxy vitamin D levels in a Swedish cohort. Endocrine 49, 800-808.

45. Richter K, Breitner S, Webb AR, et al. (2014) Influence of external, intrinsic and individual behaviour variables on serum $25(\mathrm{OH}) \mathrm{D}$ in a German survey. J Photochem Photobiol B 140, 120-129.

46. Merlo C, Trummler M, Essig S, et al. (2015) Vitamin D deficiency in unselected patients from Swiss Primary Care: a cross-sectional study in two seasons. PLOS ONE 10, e0138613.

47. Looker AC, Dawson-Hughes B, Calvo MS, et al. (2002) Serum 25-hydroxyvitamin D status of adolescents and adults in two seasonal subpopulations from NHANES III. Bone 30, 771-777.

48. Cashman KD, Muldowney S, McNulty B, et al. (2013) Vitamin D status of Irish adults: findings from the National Adult Nutrition Survey. Br J Nutr 109, 1248-1256.

49. Littorin B, Blom P, Scholin A, et al. (2006) Lower levels of plasma 25-hydroxyvitamin D among young adults at diagnosis of autoimmune type 1 diabetes compared with control subjects: results from the nationwide Diabetes Incidence Study in Sweden (DISS). Diabetologia 49, 2847-2852.

50. Nakamura K, Nashimoto M, Hori Y, et al. (2000) Serum 25-hydroxyvitamin D concentrations and related dietary factors in peri- and postmenopausal Japanese women. Am J Clin Nutr 71, $1161-1165$

51. Cashman KD, FitzGerald AP, Viljakainen HT, et al. (2011) Estimation of the dietary requirement for vitamin $\mathrm{D}$ in healthy adolescent white girls. Am J Clin Nutr 93, 549-555.

52. Petersen RA, Larsen LH, Damsgaard CT, et al. (2017) Common genetic variants are associated with lower serum 25-hydroxyvitamin D concentrations across the year among children at northern latitudes. Br J Nutr 117, 829-838.

53. Wyness SP \& Straseski JA (2015) Performance characteristics of six automated 25-hydroxyvitamin D assays: Mind your $3 \mathrm{~s}$ and $2 \mathrm{~s}$. Clin Biochem 48, 1089-1096. 